\title{
DIKSI DALAM MANTRA BAHASA BANJAR
}

\author{
Hestiyana \\ Balai Bahasa Kalimantan Selatan \\ Pos-el: hestiyana21@gmail.com
}

\begin{abstract}
Abstrak
Penelitian ini bertujuan untuk mendeskripsikan diksi dalam mantra bahasa Banjar. Penelitian ini menggunakan metode deskriptif dengan pendekatan kualitatif untuk menganalisis data. Teknik pengumpulan data dilakukan dengan menggunakan (1) metode simak, baik simak libat cakap atau simak bebas libat cakapdan(2) teknik catat. Teknik wawancara juga digunakan dalam mengumpulan data.Analisis data dilakukan dengan pengkajian setiap teks naskah mantra untuk melihat keseluruhan gejala kelainan bahasa. Setelah dilakukan penelitian secara mendalam mengenai diksi dalam mantra bahasa Banjar dapat disimpulkan bahwa sampai saat ini masyarakat Banjar masih ada yang mempercayai mantra. Mantra ini menjadi alternatif pilihan pengobatan penyakit yang sering dialami sehari-hari. Dari hasil penelitian jugaditemukan adanya penggunaan pilihan kata atau diksi. Pilihan kata atau diksi mencakup diksi dengan makna denotatif, diksi dengan makna konotatif, diksi dengan makna sinonim, diksi dengan makna antonim, diksi dengan makna homonim, diksi dengan simbol-simbol agama, dan diksi yang berhubungan dengan budaya.
\end{abstract}

Kata kunci: diksi, mantra,bahasa Banjar

\begin{abstract}
This study aims to describe diction in spell in Banjar language. This research uses descriptive method with qualitative approach to analyze the data. Data is collected using (1) listening methods, either conversation engage listening or conversation engage free listening and (2) log writing technique. Interview technique is also used in gathering data. Data analysis is performed by studying each manuscripts of spells to find out the overall symptoms of language disorders. After in-depth research on diction in spellin Banjar languageit can be concluded that up to now there are people in Banjar community who believe inspell. Spell has become an alternative treatment that is often used for commondisease. The research finds out that there isapplicationof word choice or diction. Diction includes diction with denotative meaning, connotative meaning, synonym meaning, antonym meaning, homonym meaning, religious symbolic meaning, and cultural meaning.
\end{abstract}

Key words: diction, spell, Banjar language

\section{PENDAHULUAN}

Sebuah karya sastra, baik sastra lisan ataupun tulisan, diciptakan dengan memiliki fungsi bagi masyarakat. Dalam menyampaikan ide dan gagasan dalam sebuah karya sastra tentunya menggunakan media bahasa sebagai alat pengungkap pesan. Dalam tujuan artistik, bahasa digunakan sebagai media dalam karya sastra yang diolah dengan ide-ide serta gagasan yang seindah-indahnya guna pemuasan rasa estetika manusia.
Bahasa mempunyai fungsi utama sebagai sarana untuk menyampaikan informasi melalui jalinan-jalinan komunikasi. Bahkan, bahasa digunakan ketika seseorang bermaksud mengekspresikan perasaannya, baik dengan diri sendiri ataupun orang lain. Bahasa juga digunakan untuk mengungkapkan perasaan, pikiran, serta gagasan. Hal ini dapat dilihat dari fungsi bahasa untuk artistik, yakni dengan mengolah dan menggunakan bahasa dengan seindahindahnya guna pemuasan rasa estetis manusia. 
Fungsi utama bahasa ialah sebagai alat komunikasi dan alat berpikir. Bahasa sebagai alat komunikasi memungkinkan manusia dapat saling berhubungan dengan sesamanya, baik secara lisan maupun secara tertulis. Bahasa sebagai alat berpikir memungkinkan seseorang dapat mengembangkan berbagai macam gagasan tentang bidang-bidang kehidupan yang dihadapinya (Sutana, 2015:2).

Bahasa memiliki fungsi-fungsi yang digunakan didasarkan atas tujuan. Klasifikasi fungsi-fungsi bahasa menurut Holmes (1992: 286) dibagi dalam enam fungsi, yaitu:(1) fungsi ekspresif (untuk mengekspresikan perasaan pembicara);(2) fungsi direktif (untuk meminta seseorang untuk melakukan sesuatu);(3) fungsi referensial (untuk menyediakan informasi);(4) fungsi metalinguistik (untuk mengomentari tentang bahasa itu sendiri);(5) fungsi puitis (untuk memfokuskan karakteristik bahasa yang estetik, misalnya puisi, moto, dan ritme); dan (6) fungsi fatis (untuk mengekspresikan suatu solidaritas dan empati kepada orang lain).

Fungsi bahasa menurut model Leech (dalam Usman, 2009:48) ada lima fungsi bahasa, yaitu: (1) fungsi informasional, yaitu fungsi pembawa informasi: (2) fungsi ekspresif, yaitu fungsi untuk mengungkapkan perasaan dan sikap penutur; (3) fungsi direktif, yaitu fungsi memengaruhi perilaku atau sikap orang lain, lebih memberikan tekanan pada sisi penerima, bukan pada penutur; (4) fungsi estetik, yaitu fungsi penggunaan bahasa demi hasil karya itu sendiri dalam menciptakan efek artistik, dan (5) fungsi fatik, yaitu fungsi untuk menjaga agar garis komunikasi tetap terbuka, untuk menjaga hubungan sosial secara baik. Oleh karena itu, mantra sebagai karya sastra mempunyai fungsi estetik karena selain untuk mengekspresikan nilai-nilai artistiknya juga terdapat fungsi penggunaan bahasa dalam mengungkapkan karakteristik bahasanya.

Bahasa dalam karya sastra memiliki unsur penting karena melalui bahasa seorang pengarang sastra dapat mengungkapkan berbagai ide, gagasan, atau pesan yang berupa nilai-nilai pendidikan, moral, maupun nilai-nilai religius atau agama melalui karya sastranya (Susilawati, 2016:43).Kelebihan suatu karya sastra terletak pada penggunaan bahasa yang digunakan, pilihan-pilihan kata yang disampaikan, dan juga makna yang diungkapkan. Karakteristik bahasa dalam karya sastra tidak hanya sebagai alat penyampai pesan, lebih dari itu memberi makna yang lebih luas terhadap hubungan antara karya sastra dengan manusia. Dalam karya sastra terdapat komunikasi antara pencipta atau pengarang dengan penikmatnya.

Bertolak pada kenyataan di atas, tidak dapat disangkal akan keberadaan puisi Banjar genre lama, khususnya mantra. Mantra sendiri memiliki pengertian perkataan atau ucapan yang dapat mendatangkan daya gaib (misalnya dapat menyembuhkan, mendatangkan celaka, dan sebagainya), susunan kata berunsur puisi (seperti rima, irama) yang dianggap mengandung kekuatan gaib, biasanya diucapkan oleh dukun atau pawang untuk menandingi kekuatan gaib yang lain; puisi yang diresapi oleh kepercayaan akan dunia gaib; irama bahasa sangat penting untuk menciptakan nuansa magis, mantra timbul dari kepercayaan animisme (Laelasari dan Nurlailah, 2008:153).

Mantra merupakan salah satu produk sastra sebagai sebuah kebudayaan yang pernah mewarnai kehidupan masyarakat di nusantara. Mantra bisa berupa puisi lisan yang berpotensi memiliki kekuatan gaib atau semacam doa yang memanfaatkan bahasa lokal dengan didasari oleh keyakinan yang telah diwariskan oleh para leluhur. Mantra agar dapat dimanfaatkan tidak cukup untuk sekedar dihapalkan, tetapi harus disertai laku mistik (Saputra, 2007:xxv).

Pada zaman modern dengan kemajuan pengobatan yang semakin canggih, ternyata masih menyisakan ruang bagi sastra lisan, seperti mantra sebagai pilihan alternatif pengobatan di pelosok-pelosok daerah. Pengobatan tradisional lebih cenderung menggunakan jasa 
orang pintar atau dukun dalam usaha pengobatan berbagai penyakit yang diderita. Masyarakat lebih memilih pengobatan tersebut karena dianggap lebih terjangkau daripada pengobatan ilmu medis. Sulitnya mengakses sarana kesehatan di pelosok desa juga menjadi pilihan untuk memilih pengobatan tradisional.Dengan demikian, mantra menjadi pilihan berobat dan dipercaya dapat digunakan sebagai sarana untuk mencapai berbagai keinginan yang berobat.

Puisi Banjar genre lama merupakan puisi berbahasa Banjar yang bentuk fisiknya merujuk kepada genre puisi lama atau tradisional (Sulistyowati dan Tajuddin, 2012:19). Kemudian, dijelaskan lagi oleh Sulistyowati dan Tajuddin (2012:21) bahwa berdasarkan karakteristik bentuk fisik dan bentuk mentalnya, puisi Banjar genre lamadapat dipilih-pilih menjadi lima kelompok besar, yaitu: (1) puisi Banjar genre lama bercorak madihin; (2) puisi Banjar genre lama bercorak mantra; (3) puisi Banjar genre lama bercorak pantun; (4) puisi Banjar genre lama bercorak peribahasa; dan (5) puisi Banjar genre lama bercorak syair. Mantra panawar termasuk dalam puisi Banjar genre lama yang bercorak mantra.

Secara etimologis, panawar berasal dari kosa kata bahasa Banjar tawar, artinya dibuat menjadi tawar atau dibuat menjadi netral (hilang rasa asinnya, manisnya, dan pahitnya). Panawar artinya segala sesuatu yang dapat dijadikan sebagai alat penawar, penetral, atau penghilang. Panawar adalah mantra Banjar yang difungsikan sebagai sarana magis untuk mengobati penyakit yang diderita orang lain yang datang berobat kepada penggunanya (Sulistyowati dan Tajuddin, 2012:79). Dengan demikian, mantra panawar merupakan mantra yang digunakan sebagai sarana pengobatan bagi masyarakat Banjar.

Mantra yang juga merupakan media komunikasi menggunakan bahasa sebagai penyampai pesan. Keberadaan mantra, terutama mantra panawardalam masyarakat Banjar sebagai media komunikasi semakin tampak ketika terjadi kegiatan keagamaan. Humaedi (2016:7) menyatakan bahwa praktik pengobatan kerap mencakup di dalamnya praktik ritual kepercayaan. Aspek ritual menjadi bagian terpenting proses pengobatan karena menegaskan ketundukan terhadap sesuatu yang transenden, sesuatu Yang Suci.

Pengaruh puisi lisan tidak harus bergantung pada sifat permanen teks, tetapi pada lingkungan sekitar tempat puisi lisan (Sudikan, 2001:115). Secara umum, puisi lisan meliputi ritual penyembuhan, penyelesaian perselisihan, menambah kekhidmatan upacara, dan memberi kenyamaan bagi yang mempercayainya.

Mantra panawar ini dianggap doa, dianggap memiliki kekuatan gaib (daya), diyakini dapat berkomunikasi dengan Tuhan, dengan diri sendiri, dengan orang lain, makhluk halus, serta mahluk lainnya. Tujuannya pun berbedabeda sesuai niat si pemakai mantra panawardan sesuai keperluan akan mantra tersebut.Bagi masyarakat Banjar, mantra panawar menjadi alternatif pilihan berobat selain pengobatan medis.

Mantra panawar dalam masyarakat Banjar sebagaihasil sastra Banjar genre lama yang bercorak puisi, juga merupakan media komunikasi yang tentunya menggunakan bahasa yang berbeda dengan bahasa dalam percakapan sehari-hari. Di dalam mantra panawar ini, bahasa digunakan sebagai media yang diyakini menghubungkan antara pencipta dengan masyarakat penikmat karya sastra tersebut. Menarik untuk dikaji bahwa sebuah karya sastra, terutama dalam mantra panawar, tentunya memiliki karakteristik bahasa yang unik, ter1utama diksi dalam mantra.

Tentunya di dalam mantrapanawar, bahasa yang digunakan lebih banyak menonjolkan nilai konotasi yang lebih luas dari pengertian denotasi. Selain itu, karakteristik bahasa lebih bersifat simbolis karena tidak hanya mengungkapkan yang tersurat tetapi juga tersirat. 
Oleh sebab itu, dari banyak mantra Banjar dipilihlah mantra panawar sebagai objek dalam penelitian ini. Mengingat dalam mantra $p a-$ nawar dimunculkan pilihan kata permohonan agar orang yang sakit dapat disembuhkan.

Sejauh ini penelitian mengenai Diksi dalam Mantra Bahasa Banjar sangat sedikit sekali. Penelitian yang mencoba mengkaji tentang mantra pun jumlahnya masih sedikit. Penelitian yang telah ada antara lain: Fungsi Mantra dalam Masyarakat Banjar oleh Ismail, dkk (1996) dan Mantra Banjar oleh Yayuk, dkk (2006). Penelitian yang dilakukan oleh Ismail, dkk (1996) mengungkap fungsi-fungsi mantra. Kemudian, Yayuk, dkk (2006) mengklasifikasikan jenis-jenis mantra Banjar dalam empat macam mantra, yakni jenis pitua, pirunduk, tatamba, dan tutulak.

Pitua adalah mantra yang digunakan hanya untuk kepentingan pemakainya, tetapi tidak merugikan orang lain. Pirunduk adalah mantra yang digunakan untuk menundukkan orang lain. Kemudian, tatamba adalah segala jenis mantra yang digunakan dalam pengobatan, baik pengobatan penyakit jasmaniah maupun penyakit rohaniah. Selanjutnya, tutulak adalah mantra untuk menolak bahaya atau penyakit dan merupakan perisai diri (Yayuk, dkk, 2006:64).

Informasi di atas menunjukkan bahwa penelitian mengenai mantra Banjar masih sedikit dan perlu untuk dilakukan, terutama Diksi dalam Mantra Bahasa Banjar yang belum terjamah. Oleh sebabitu, perlu dilakukan penelitian tentang diksi dalam mantra bahasa Banjarmengingat penelitian terdahulu tidak membahas tentang itu. Penelitian yang dilakukan oleh Ismail, dkk (1996) sebatas mengungkap fungsi-fungsi mantra, sedangkan Yayuk, dkk (2006) hanya mengklasifikasikan mantra Banjar. Kedua penelitian terdahulu tersebut tidak sedikit pun menyinggung diksi dalam mantra bahasa Banjar, terutama mantra panawar.

Dengan demikian, masalah penelitian ini adalah bagaimanakah diksi dalam mantra bahasa Banjar? Tujuan yang ingin dicapai dalam penelitian ini adalah untuk mendeskripsikan diksi dalam mantra bahasa Banjar. Hasil penelitian ini diharapkan dapat memberikan informasi yang lebih spesifik dan mendalam mengenai diksi dalam mantra bahasa Banjar, terutama mantra panawar.

Kajian bahasa mantra panawar tentunya akan menambah kekayaan linguistik mengenai bahasa yang digunakan dalam mengekspresikan nilai-nilai mantra panawar tersebut. Kajian mengenai mantra panawarjuga sebagai bentuk pelestarian warisan leluhur serta mampu membuktikan bahwa masyarakat Banjar memiliki kekayaan budaya yang layak diteliti. Selanjutnya, hasil penelitian ini diharapkan dapat dijadikan bahan serta acuan bagi penelitian-penelitian selanjutnya.

\section{TEORI DAN METODE}

Bahasa dalam karya sastra memiliki keterkaitan yang yang sangat erat. Hal ini seperti yang diungkapkan Nurgiyantoro (2012:272) bahwa bahasa dalam seni sastra dapat disamakan dengan cat dalam seni lukis. Keduanya merupakan unsur bahan, alat, sarana yang diolah untuk dijadikan sebuah karya yang mengandung "nilai lebih" daripada sekedar bahannya itu sendiri. Di pihak lain sastra lebih dari sekedar bahasa, deretan kata, namun unsur kelebihannya itu pun hanya dapat diungkap dan ditafsirkan melalui bahasa. Dengan demikian, jelaslah bahwa dalam mengungkapkan atau menyampaikan sebuah karya sastra hanya dapat dikomunikasikan melalui sarana bahasa.

Dengan melihat estetika bahasa yang terdapat dalam mantra maka penelitian ini melihat wujud pilihan kata (diksi). Hal ini seperti yang diungkapkan Keraf (2006:22) bahwa pengertian pilihan kata atau diksi jauh lebih luas dari apa yang dipantulkan oleh jalinan kata-kata itu. Diksi dapat mencakup diksi dengan makna denotatif, diksi denganmakna konotatif, diksi dengan makna sinonim, diksi 
dengan makna antonim, diksi dengan makna homonim, diksi dengan makna simbol-simbol agama, dan diksi yang berhubungan dengan makna budaya.

Diksi atau pilihan kata adalah penentuan kata yang tepat, selaras dan berefek dalam konteks penggunaan untuk penggambaran gagasan. Artinya, diksi yang dipilih dalam mantra itu telah memiliki jiwa (perasaan-perasaan) yang maknanya disesuaikan dengan fungsi dan tujuan makna mantra. Diksi yang dimaksud meliputi kata yang maknanya dapat langsung dimengerti (denotatif) dan kata yang maknanya perlu penjabaran (konotatif).

Nurgiyantoro (2012:273) menyatakan bahwa pemahaman pembaca akan mengacu dari makna denotatif atau paling tidak makna itu akan dijadikan dasar pijakan. Sebaliknya, makna konotatif pun banyak dijumpai dan dipergunakan dalam penggunaan bahasa yang lain, yang tidak tergolong karya kreatif, seperti bentuk-bentuk tertentu metafor yang justru dapat memperjelas makna yang dimaksud daripada bahasa yang lugas.

Keraf (2006:28) menyebut makna denotatif dengan beberapa istilah lain seperti makna denotasional, makna kognitif, makna konseptual, makna ideasional, makna referensial, atau makna proposisional. Disebut makna denotasional, referensial, konseptual, atau ideasional karena makna itu menunjuk (denote) kepada suatu referen, konsep, atau idetertentu dari suatu referen. Disebut makna kognitif karena makna itu bertalian dengan kesadaran atau pengetahuan; stimulus (dari pembicara) dan respons (dari pihak pendengar) menyangkut hal-hal yang dapat diserap pancaindria (kesadaran) dan rasio manusia. Disebut makna proposisional karena bertalian dengan informasi-informasi atau pernyataan-pernyataan yang bersifat faktual.

Selanjutnya, Keraf (2006:29) menyebut makna konotatif adalah suatu jenis makna di mana stimulus dan respons mengandung nilainilai emosional. Konotasi atau makna konotatif disebut juga makna konotasional, makna emotif, atau makna evaluatif. Pendapat yang sama juga dikemukakan Kridalaksana (2011:132) bahwa aspek makna sebuah atau sekelompok kata yang didasarkan atas perasaan atau pikiran yang timbul atau ditimbulkan pada pembicara (penulis) dan pendengar (pembaca).

Putrayasa (2010:10) menyatakan bahwa sebuah kata yang hanya mengacu pada makna konseptual atau makna dasar berfungsi denotatif, sedangkan kata lain yang merupakan gambaran tambahan yang mengacu pada nilai dan rasa berfungsi konotatif. Makna konotasi dibedakan menjadi dua bagian, sebagaiberikut: (1) konotasi positif, yaitu makna tambahan dari makna kata sebenarnya yang bernilai rasa tinggi, baik, sopan, santun, sakral, dan sejenisnya; dan (2) konotasi negatif, yaitu makna tambahan dari makna kata sebenarnya yang bernilai rasa rendah, kotor, porno, jelek, jorok, dan sejenisnya.

Menurut Chaer (2012:292) makna denotatif adalah makna asli, makna asal, atau makna sebenarnya yang dimiliki oleh sebuah leksem. Makna konotatif adalah makna lain yang "ditambahkan" pada makna denotatif yang berhubungan dengan nilai rasa dari orang atau kelompok orang yang menggunakan kata tersebut.

Dengan demikian, makna denotatif merupakan makna yang sebenarnya, makna asal atau makna yang paling mendasar dalam sebuah kata, sedangkan makna konotatif merupakan makna yang ditambahkan pada makna denotatif yang berkaitan dengan nilai rasa. Makna konotatif ini timbul karena adanya hubungan masalah sosial ataupun hubungan interpersonal dengan orang lain.

Sinonimi adalah suatu istilah yang dapat dibatasi sebagai (1) telaah mengenai bermacam-macam kata yang memiliki makna yang sama atau (2) keadaan di mana dua kata atau lebih memiliki makna yang sama (Keraf, 2006:34). Dengan kata lain, sinonim merupakan kata-kata yang memiliki makna yang sama. 
Pendapat yang sama juga dikemukakan oleh Chaer(2012:297) bahwa sinonim atau sinonimi adalah hubungan semantik yang menyatakan adanya kesamaan makna antara satu satuan ujaran dengan satuan ujaran lainnya.

Arifin, dkk (2015:68) menyatakan bahwa sinonim adalah dua kata atau lebih yang maknanya sama atau mirip, tetapi bentuknya berlainan. Di antara kata yang bersinonim tersebut ada kata yang diutamakan. Dengan demikian, sinonim atau sinonimi merupakan hubungan dua kata atau lebih yang saling memiliki kesamaan makna atau beberapa kata yang memiliki makna yang mirip.

Menurut Keraf (2006:39) istilah antonimi adalah relasi antar makna yang wujud logisnya sangat berbeda atau bertentangan. Antonim atau antonimi adalah hubungan semantik antara dua buah satuan ujaran yang maknanya menyatakan kebalikan, pertentangan, atau kontras antara yang satu dengan yang lain (Chaer, 2012:299). Pendapat yang sama dikemukakan Arifin, dkk (2015: 69) bahwa antonim adalahkata yang berlawanan atau beroposisi. Dengan demikian, antonim merupakan kata yang menyatakan makna berlawanan atau bertentangan.

Kemudian, Keraf (2006:36) memberikan pengertian homonimi adalah dua kata atau lebih tetapi memiliki bentuk yang sama. Hal yang sama dikemukakan Arifin, dkk (2015:69) bahwa istilah homonim berupa dua kata atau lebih yang sama ejaan dan lafalnya, tetapi maknanya berbeda karena asalnya berlainan. Istilah homonim dapat dibedakan menjadi homograf dan homofon. Istilah homograf ialah kata yang sama ejaannya, tetapi berbeda lafalnya. Kemudian, istilah homofon ialah kata yang sama lafalnya, tetapi berbeda ejaannya.

Pendapat senada dikemukakan Chaer (2012:302) bahwa homonim atau homonimi adalah dua buah kata atau satuan ujaran yang bentuknya "kebetulan" sama, maknanya tentu saja berbeda karena masing-masing merupakan kata atau bentuk ujaran yang berlainan.
Kridalaksana (2011:85) menyatakan homonim merupakan hubungan antara kata yang ditulis atau dilafalkan dengan cara yang sama dengan kata lain, tetapi yang tidak mempunyai hubungan makna.

Metode yang digunakan dalam penelitian ini adalah metode deskriptif dengan pendekatan kualitatif karena bertujuan untuk mendeskripsikan diksi dalam mantra bahasa Banjar. Bogdan dan Taylor (dalam Moleong, 2002:4) menyatakan bahwa penelitian kualitatif adalah prosedur penelitian yang menghasilkan data deskriptif berupa kata-kata tertulis atau lisan tentang orang-orang atau perilaku yang diamati. Mulyana (2001:146) mengemukakan bahwa metodeatau teknik penelitian apapun yang kita gunakan, misalnya apakah kuantitatif atau kualitatif, haruslah sesuai dengan kerangka teoritis yang kita asumsikan.

Data penelitian ini adalah mantra panawar yang diperoleh dari informan di tiga kabupaten, yaitu Kabupaten Hulu Sungai Selatan, Hulu Sungai Tengah, dan Hulu Sungai Utara. Informan tersebut merupakan panambaan yang sering dimintai tolong untuk memberikan pengobatan.

Teknik pengumpulan data dilakukan dengan menggunakan cara, yaitu: (1) metode simak, baik simak libat cakap atau simak bebas libat cakap dan (2) teknik catat (Mahsun, 2013:93). Pendapat yang sama juga dikemukakan Sudaryanto (2015:203) bahwa dalam teknik simak libat cakap peneliti terlibat langsung dalam dialog, di samping memperhatikan penggunaan bahasa mitra (mitra wicaranya yang bersosok konkret juga ikut serta dalam pembicaraan mitra wicaranya itu).

Kemudian, Sudaryanto (2015:204) menambahkan bahwa di dalam teknik simak bebas libat cakap, si peneliti tidak terlibat dalam dialog, konversasi, atau imbal-wicara; jadi tidak ikut serta dalam proses pembicaraan orangorang yang saling berbicara. Peneliti hanya sebagai pemerhati yang penuh minat tekun 
mendengarkan apa yang dikatakan (dan bukan apa yang dibicarakan) oleh orang-orang.

Selanjutnya, Mahsun (2013:93) menyatakan bahwa teknik catat adalah teknik lanjutan yang dilakukan ketika menerapkan metode simak. Menurut Subroto (1992:41), teknik catat adalah teknik yang digunakan untuk mencatat data-data yang ditemukan ke dalam nota pencatat yang telah disiapkan. Dengan demikian, teknik catat digunakan sebagai teknik lanjutan dari teknik sebelumnya yang digunakan dalam pengambilan data di lapangan.

Dalam penelitian ini, teknik simak libat cakap dilakukan dengan cara berpartisipasi sambil menyimak pembicaraan dan langsung terlibat dalam dialog dengan informan, sedangkan dalam teknik simak bebas libat cakap, pengambilan data hanya sekedar mengamati penggunaan tuturan mantra panawar yang dituturkan oleh informan. Kemudian, teknik catat merupakan teknik lanjutan yang dilakukan dengan mencatat data ataupun informasiinformasi mengenai mantra panawar dari informan.

Keabsahan data dicek dengan teknik triangulasi data, yakni diskusi teman sejawat. Pemeriksaan teman sejawat adalah melakukan diskusi dengan teman yang pernah melakukan penelitian mantra. Hasil diskusi dengan teman sejawat tersebut disesuaikan dengan hasil mantra yang ditemukan di lapangan.

Dalam pengumpulan data juga dilakukan wawancara dengan teknik berputar-putar baru menukik, maksudnya pada awal wawancara dibicarakan hal-hal yang tidak terkait dengan tujuan, dan bila sudah terbuka kesempatan akan ditanyakan mantra panawar kepada informan. Hal ini dilakukan karena untuk pengumpulan data mantra panawar itu sendiri bukanlah hal yang mudah. Penyerahan mantra panawar pun harus disertai dengan syaratsyarat tertentu. Salah satu syaratnya adalah piduduk atau sejenis sesaji.

Biasanya piduduk ini berisi beras 3,5 liter, sebongkah gula merah, bubur merah, bubur putih, garam, jarum, dan benang. Piduduk tersebut diserahkan kepada panambaan yang menjadi informan penelitian ini sebagai syarat sebelum dilakukannya wawancara. Meskipun syarat piduduk sudah dipenuhi, informan juga tidak akan sembarang memberikan data dan informasi karena mantra panawar dianggap sebuah simbol warisanturun-temurun yang hanya boleh diberikan kepada anak cucu mereka. Akan tetapi, ada sebagian mantra panawar yang boleh dipublikasikan dan mantra yang memang menjadi sesuatu yang dianggap warisan keluarga.

Analisis data dilakukan dengan pengkajian setiap teksnaskah mantra panawar untuk melihat keseluruhan gejala kelainan bahasa. Tidak hanya pada tingkat kata,frase, klausa, ungkapan, bahkan pada tingkat kalimat. Selain itu, tujuan penggunaanmantra panawarjuga perlu dipahami serta makna dari tiap larik puisi mantrapanawar. Tujuannya adalahuntuk menemukan pilihan kata atau diksi dan makna yang ditimbulkannya.

Untuk menyajikan hasil analisis data penelitian ini, digunakan teknik informal. Hal ini seperti yang dikemukakan Sudaryanto (1993: 145) bahwa teknik informal adalah perumusan dengankata-kata biasa tanpa lambang-lambang atau simbol. Dengan penyajian analisis informal ini, penyajian hasil analisis diksi dalam mantra bahasa Banjar, berupa wujud pilihan kata (diksi).

\section{HASIL DAN PEMBAHASAN}

Di dalam mantra panawar, karakteristik kebahasaan terlihat dari rangkaian kata-kata yang diungkapkan. Untuk memahami estetika kebahasaan yang terdapat dalam mantra panawar hanya dapat diwujudkan dengan cara menganalisis mantra tersebut melalui pilihan kata atau diksi.Dalam praktik fungsionalisasinya di lapangan, semua mantra panawar harus dibaca ulang secara utuh dalam hitungan ganjil dari 3,5,7,9, dan seterusnya. Hampir semua mantra panawar yang dituturkan pa- 
nambaan diawali dengan kalimat bismillaahir rahmaanir rahiim. Hal ini sesuai dengan keyakinan masyarakat Banjar yang mayoritas beragama Islam, menganggap bahwa mantra panawar sebagai sarana doa untuk kesembuhan.

Dalam mantra panawar ini dikaitkan dengan unsur-unsur ketaatan kepada Yang Mahakuasa. Hal ini menunjukkan bahwa tergambar sikap masyarakat Banjar yang taat kepada penguasa semesta.Ciri utama mantra panawar ini terletak pada pilihan kata yang berisi permohonan agar orang yang diobati segera sembuh dari penyakitnya. Berikut hasil analisis diksi dalam mantra bahasa Banjar.

\section{Diksi dengan Makna Denotatif}

Dalam mantra panawar ditemukan diksi dengan makna denotatif, yaitu pada mantra mengusir pulasit. Pulasit merupakan makhluk halus atau makhluk gaib yang bisa merasuki seseorang. Jadi pulasit dalam masyarakat Banjar apabila seseorang yang terkena kerasukan atau kesurupan. Berikut hasil analisisnya.

Mantra Mengusir Pulasit

Bismillaahir rahmaanir rahiim

Bulik ikam, bila kada bulik

Ikam kugundul, bulik

Bila kada bulik

Ikam kugundul nang kaya nyiur ini

\section{Terjemahan:}

Mantra Mengusir Pulasit

Dengan nama Allah Tuhan Yang Maha

Pengasih lagi Maha Penyayang

Pulang kau, bila tidak pulang

Kau kugundul, pulang

Bila tidak pulang

Kau kugundul seperti kelapa ini

Mantra mengusir pulasit ini tidak sembarang panambaan dapat memberikan panawarnya karena bersifat rahasia dan harus memiliki kekuatan supranatural. Dengan menggunakan mantra panawar ini, panambaan berusaha mengusir dan menyadarkan orang yang terkena pulasit tersebut dengan berkali-kali membaca mantra. Biasanya, panambaan memegang buah kelapa yang siap digunduli dengan parang sebagai bentuk ancaman kepada hantu pulasit.

Mantra mengusir pulasit di atas menggunakan pilihan kata dengan makna denotatif yang dapat dilihat dari tiap lirik-lirik mantra tersebut. Diksi yang digunakan dalam penyampaian mantra itu menggunakan karakteristik bahasa yang langsung merujuk kepada makna sebenarnya. Dalam mantra panawar mengusir pulasit ini, kalimat-kalimat yang dituturkan $p a-$ nambaan tidak bermakna tambahan, makna lain atau konotatif.

Pilihan kata bulik ikam, bila kada bulik ikam kugundul, bulik "pulang kau, bila tidak pulang kau kugundul, pulang" langsung merujuk kepada seseorang. Dalam hal ini, penyebab munculnya pulasit, yaitu dari alam gaib yang sering disebut oleh masyarakat Banjar hantu pulasit. Demikian juga kalimat mantra panawarbila kada bulik ikam kugundul nang kaya nyiur ini langsung mengacu kepada makna asli atau makna dasar. Tujuan mantra panawar mengusir pulasit tersebut, apabila hantu pulasit tidak pergi akan digundul kepalanya seperti kelapa. Jadi, ketika seseorang meminta panambaan untuk mengobati terkena pulasit ini harus menggunakan media buah kelapa yang sudah dikupas kulitnya.

\section{Diksi denganMakna Konotatif}

Dalam mantra panawar ditemukan diksi dengan makna konotatif, yaitu mantrapanawar manyamak (mantra penawar sakit pada bagian dada atau tulang belakang yang disebabkan masuk angin). Berikut hasil analisisnya.
Mantra Panawar Manyamak
Bismillaahir rahmaanir rahiim
Caricit burung caricit
Hinggapnya di batang tawar
Datu nang mana nang manyumpit
Bismillaahir rahmaanir rahiim
Aku manawar 


\section{Terjemahan:}

Mantra Panawar Manyamak (Mantra

Terkena Angin Duduk)

Dengan nama Allah Tuhan Yang Maha

Pengasih lagi Maha Penyayang

Mencicit burung mencicit

Hinggapnya di batang tawar

Datu mana yang menyumpit

Bismillaahir rahmaanir rahiim

Aku memantrai

Seorang panambaan dalam proses mengobati sakit manyamak ini menggunakan daun sirih yang ditempelkan pada bagian tubuh yang sakit. Bisa juga panambaan menggunakan kunyit dan kapur yang ditempelkan dan sambil ditiup pada bagian tubuh yang sakit. Proses pengobatan dengan mantra panawarmanyamak ini bertujuan agar angin duduk yang terdapat di bagian dalam lapisan kulit yang sakit akan hilang.

Mantra panawar manyamak di atas menggunakan pilihan kata dengan makna konotatif yang dapat dilihat pada kalimathinggapnya di batang tawar. Kalimat tersebut menunjukkan makna lain yang "ditambahkan" pada makna denotatif yang berhubungan dengan nilai rasa. Kalimat hinggapnya di batang tawar dalam mantra panawar manyamak tersebut mengacu kepada burung yang sedang mencicit dan hinggap di batang tawar. Frasebatang tawar tidak memiliki makna yang sebenarnya karena menjadi bagian dari makna tambahan dari kalimat sebelumnya. Hal ini dimaksudkan tawar atau obat bagi yang sakit.

Kalimat mantra Datu nang mana nang manyumpit "Datu mana yang menyumpit" juga memiliki nilai rasa lain atau makna tambahan. Datu yang dimaksud dalam mantra ini adalah sesuatu yang berasal dari alam gaib, seperti jin atau hantu penunggu suatu tempat. Dengan dibacanya mantra ini, diharapkan orang yang terkena sakit manyamak akan segera sembuh.

\section{Diksi dengan Makna Sinonim}

Dalam mantra panawar ditemukan diksi dengan makna sinonim, yaitu mantra panawar urang halin baranak (penawar memudahkan melahirkan karena posisi kandungan terbalik atau sungsang). Berikut hasil analisisnya.

Mantra Panawar Urang Halin Baranak
Bismillaahir rahmaanir rahiim
Bungkalang bungkaling
Tampurung bulu-bulu
Takalang tapaling
Ka luar tadahulu
Barakat Laa Ilaaha Illallah
Muhammadarrasullullah

\section{Terjemahan:}

Penawar Memudahkan Melahirkan karena Posisi Kandungan Terbalik atau Sungsang

Dengan nama Allah Tuhan Yang Maha

Pengasih lagi Maha Penyayang

Terkalang terkaling

Tempurung berbulu

Terkalang terpaling

Keluar lebih dulu

Berkat Laa Ilaaha Illallah

Muhammadarrasullullah

Mantra panawar urang halin baranak digunakan oleh panambaan untuk menolong ibu yang mengalami kesulitan melahirkan. Biasanya, masyarakat Banjar menyebutnya dengan banyu palungsurbaranak(air yang sudah dibaca mantra untuk melancarkan persalinan). Selain panambaan, banyu palungsur ini juga bisa diberikan oleh dukun baranak (dukun beranak).

Kata yang bersinonim dalam mantra $p a-$ nawar urang halin baranak di atas, yaitu bungkalang bungkaling (terkalang terkaling) dan $t a-$ kalang tapaling (terkalang terpaling). Kalimat bungkalang bungkaling (terkalang terkaling) dimaksudkan posisi bayi dalam perut si ibu yang terkalang akan kembali menuju jalan lahir. Begitu juga kalimat takalang tapaling (terkalang terpaling) yang bersinonim dengan bungkalang bungkaling (terkalang terkaling) dimaksudkan posisi bayi yang sedang terkalang dalam perut si ibu. Dengan diucapkannya mantra tersebut 
oleh panambaan ataupun dukun beranak diharapkan si ibu akan melahirkan dengan lancar.

\section{Diksi dengan Makna Antonim}

Dalam mantra panawar ditemukan diksi dengan makna antonim, yaitu mantra panawar penahan darah. Berikut hasil analisisnya.

Mantra Panahan Darah

Allahumma si lantung bumi

Hangat ari ranggang bumi

Hujan ari rapat bumi

Bin kulibin kuppatin

Bikun siit si pulan

\section{Terjemahan:}

Mantra Penahan Darah

Allahumma si lantung bumi

Panas hari renggang bumi

Hujan hari rapat bumi

Bin kulibin kuppatin

Bikun siit si pulan

Mantra penahan darah dibaca untuk menahan darah yang keluar dari bagian tubuh. Mantra ini dibaca panambaan ketika ada seseorang yang terluka dan untuk mengobatinya dibacalah mantra ini dalam segelas air. Kemudian, air tersebut bisa langsung diminum dan disiram perlahan pada bagian tubuh yang terluka sambil diberi ramuan penahan darah.

Kata yang berantonim dalam mantra $p a-$ nawar panahan darah (mantra penahan darah) tersebut, yaitu hangat ari (panas hari) dengan hujan ari (hujan hari) serta ranggang bumi (renggang bumi) dengan rapat bumi (rapat bumi). Frasahangat ari (panas hari) dengan hujan ari (hujan hari) merupakan frasayang memiliki makna berlawanan. Pada mantra tersebut, hangat ari (panas hari) bermakna hari yang panas atau keadaan hari yang cerah dan panas. Frasahujan ari (hujan hari) merupakan hari dalam keadaan hujan atau keadaan hari yang tidak panas. Jadi, frasahangat ari (panas hari) dengan hujan ari (hujan hari) memiliki makna yang berlawanan.
Begitu juga dengan ranggang bumi (renggang bumi) dengan rapat bumi (rapat bumi) yang memiliki makna berlawanan. Frasa ranggang bumi (renggang bumi) dalam mantra tersebut memiliki makna keadaan bumi yang renggang karena keadaan hangat ari (panas hari). Kemudian, rapat bumi (rapat bumi) dalam mantra tersebut memiliki makna keadaan bumi yang rapat karena keadaan hujan ari (hujan hari). Jadi, frasaranggang bumi (renggang bumi) dengan rapat bumi (rapat bumi) memiliki makna yang saling berlawanan. Dengan demikian, dalam mantra penahan darah tersebut ditemukan dua buah kata/frasa yang berantonim.

\section{Diksi dengan Makna Homonim}

Dalam mantra panawar ditemukan diksi dengan makna homonim, yaitu mantra panawar agar tahan gigitan lebah. Berikut hasil analisisnya.

Mantra Panawar agar Tahan Diigut Tawon
Bismillaahir rahmaanir rahiim
Asal dari kajian wanyi
Adalah karak nasi
Jumput dan makan asalnya
Barakat Laa Ilaaha Illallah
Muhammadarrasullullah
Terjemahan:
Mantra Panawar agar Tahan Digigit Lebah
Dengan nama Allah Tuhan Yang Maha
Pengasih lagi Maha Penyayang
Asal terjadinya tawon dan sejenisnya
Adalah kerak nasi
Ambil dan pergunakan sesudahnya
Berkat Laa Ilaaha Illallah
Muhammadarrasullullah

Mantra panawar agar tahan digigit lebah digunakan apabila seseorang ingin melintasi sarang tawon dengan berjalan kaki. Kalau hanya ingin melintas, mantra yang dibaca cukup sampai kalimat asal dari kajian wanyi adalah karak nasi barakat Laa Ilaaha Illallah Muhammadar rasullullah "asal terjadinya tawon dan sejenis- 
nya adalah kerak nasiberkat Laa Ilaaha Illallah Muhammadarrasullullah. Akan tetapi, apabila mantra tersebut digunakan untuk mengambil anak tawon dan madunya, ada tambahan kalimat mantra lagi, yaitu jumput dan makan asalnya barakat Laa Ilaaha Illallah Muhammadar rasullullah" ambil dan pergunakan sesudahnya berkat Laa Ilaaha Illallah Muhammadar rasullullah".

Setelah mantra itu dibaca kemudian ditiupkan ke arah sarang tawon tersebut. Mantra ini bertujuan agar orang yang melintas dekat sarang tawon ataupun ketika ingin mengambil anak tawon dan madunya tidak digigit. Masyarakat Banjar menyebutnya dengan ungkapan wanyinya kada baliur "tawonnya tidak berselera".

Mantra panawar agar tahan gigitan lebah di atas menggunakan pilihan kata dengan makna homonim yang dapat dilihat pada kata asalyang bermakna "asal atau mula-mula terjadinya sesuatu" dan asal yang bermakna "pergunakan sesudahnya". Kedua kata asal tersebut digunakan dalam satu mantra panawar dengan makna yang berbeda.

\section{Diksi dengan Makna Simbol-Simbol Agama}

Dalam mantra panawar ditemukan diksi dengan makna yang menunjukkan simbolsimbol agama Islam. Berikut hasil analisisnya.

\section{Mantra Penghilang Sakit ketika Hendak Melahirkan \\ Bismillaahir rahmaanir rahiim \\ Nun kalamun walayar turun \\ Insha Allah inya ilang aritan \\ Inya turun \\ Barakat Laa Ilaaha Illallah \\ Muhammadarrasullullah}

\section{Terjemahan:}

Mantra Penghilang Sakit ketika Hendak Melahirkan

Dengan nama Allah Tuhan Yang Maha Pengasih lagi Maha Penyayang

Tuhan yang mengetahui sebenarnya demi pena yang mereka tuliskan
Dengan izin Allah dia hilang rasa

Dia turun

Berkat Laa Ilaaha Illallah

Muhammadarrasullullah

Mantra penghilang sakit ketika hendak melahirkan ini dibaca oleh panambaan ataupun dukun baranak (dukun beranak) yang membantu proses persalinan. Mantra ini dibaca berulang-ulang kali dengan harapan menghilangkan rasa sakit si ibu yang akan melahirkan serta bayi yang dilahirkan pun selamat dan sehat.

Mantra yang digunakan untuk penghilang sakit ketika hendak melahirkan menggunakan kalimat-kalimat dalam agama Islam. Masyarakat Banjar terkenal sebagai masyarakat yang religius. Karakteristik muslim melekat dalam diri masyarakat Banjar. Sejarah membuktikan bahwa Kerajaan Islam Banjar tidak bisa dipisahkan dengan bangkitnya budaya spiritual karena sejak berdirinya, Islam resmi menjadi agama kerajaan yang dianut oleh seluruh lapisan masyarakat sekaligus menjadi identitas mereka sehingga suku Banjar identik dengan Islam.

Hal ini dapat dilihat kehidupan masyarakatnya yang meyakini agama Islam sebagai ajaran dan pondasi kehidupan sehingga berpengaruh terhadap tata nilai dalam masyarakat, seperti mantra panawar penghilang sakit ketika hendak melahirkan yang sarat dengan simbol-simbol agama Islam. Simbol-simbol agama Islam muncul dari kalimat-kalimat mantra yang dituturkan.

Dengan demikian, mantra penghilang sakit ketika hendak melahirkan ini menjadi sarana atau media permohonan kepada Yang Mahakuasa. Biasanya, mantra yang sarat dengan kalimat-kalimat bernuansa religi ini dibacakan ketika kandungan sudah tujuh bulan ke atas. Bahkan, ketika menjelang kelahiran si ibu juga ikut membaca mantra ini. Hal ini dimaksudkan selain ada usaha dari panambaan atau dukun baranak (dukun beranak)juga ada doa dari si ibu yang akan melahirkan. Dengan adanya keyakinan terhadap mantra panawar ini diha- 
rapkan seseorang wanita yang akan melahirkan dan bayinya akan selamat.

\section{Diksi yang Berhubungan dengan Makna Budaya}

Dalam mantra panawar ditemukan diksi yang berhubungan dengan makna budaya, yaitu mantrapanawar takana wisa "mantra penawar terkena wisa." Berikut hasil analisisnya.

Mantra Panawar Takana Wisa

Bismillaahir rahmaanir rahiim

Aku tahu asal ikam

Ikam Datu Kacungut

Ikam Datu Kacingit

\section{Terjemahan:}

Mantra Penawar Terkena Wisa

Dengan nama Allah Tuhan Yang Maha

Pengasih lagi Maha Penyayang

Aku tahu asal Kau

Kau Datu Kacungut

Kau Datu Kacingit

Mantra panawar takana wisa(mantra penawar terkena bisa atau racun, sakit kuning) ini tidak semua panambaan bisa memberikan air tawarnya. Biasanya, panambaan merebus air dengan batu kemudian dibacakan mantra. Kemudian, panambaan menyuruh orang yang sakit wisa untuk mandi dengan air tersebut. Adapulapanambaan yang memberikan air rebusan buah kelapa untuk diminumkan kepada yang sakit. Bahkan, kalau sakitnya belum sembuh juga, panambaan akan melakukan terapi batimung.

Pada mantra panawar takana wisa, sebutan datu dalam budaya masyarakat Banjar mengacu pada sebutan untuk ulama atau orangorang saleh yang menjadi panutan,tauladan, serta dijadikan contoh konkret dalam menjalankan kehidupan bermasyarakat. Masyarakat Banjar percaya bahwa datu menjadi refleksi kehidupan dalam meningkatkan keimanan serta ketakwaan seseorang kepada Yang Mahakuasa.
Datu dipercayai memiliki ilmu yang melebihi manusia biasa serta diyakini memiliki keistimewaan yang diberikan oleh Sang Pencipta. Ketika masih hidup seseorang datu ada yang dikeramatkan. Bahkan, sampai saat meninggal hingga sekarang makam datu yang terdapat di Kalimantan Selatan masih sering diziarahi masyarakat.

Mantra penawar terkena wisa di atas menggunakan pilihan kata yang berhubungan dengan budaya, yaitu penyebutan datu. Sebutan datu dalam budaya masyarakat Banjar mengacu pada sebutan untuk orang yang dituakan. Wisaadalah salah satu penyakit yang dianggap dari alam lain sehingga dengan membaca mantra panawar takana wisa(mantra penawar terkena bisa atau racun, sakit kuning) yang menyebutkan nama Datu Kacungut dan Datu Kacingit diharapkan penyakitnya segera hilang.

\section{PENUTUP}

\section{Simpulan}

Setelah dilakukan penelitian secara mendalam mengenaidiksi dalam mantra bahasa Banjar dapat disimpulkan bahwa sampai saat ini masyarakat Banjar masih ada yang mempercayai mantra panawar. Mantra panawar ini menjadi alternatif pilihan pengobatan penyakit yang sering dialami sehari-hari.

Dalam mantra panawar ditemukan adanya penggunaan pilihan kata atau diksi.Pilihan kata atau diksi dalam mantra panawar menunjukkan kekuatan perangkat lingual. Diksi kata yang tidak memiliki makna menunjukkan bahwa mantra bersifat misterius dan tidak dapat dipahami oleh manusia umum.

Pilihan kata atau diksi mencakup diksi dengan makna denotatif, diksi dengan makna konotatif, diksi dengan makna sinonim, diksi dengan makna antonim, diksi dengan makna homonim, diksi dengan simbol-simbol agama, dan diksi yang berhubungan dengan budaya. 


\section{Saran}

Berdasarkan hasil penelitian disarankan hendaknya penelitian ini dapat dijadikan bahan acuan bagi penelitian berikutnya untuk mengkaji tentang diksi dalam mantra bahasa Banjar. Bagi peneliti lanjutan dapat melakukan penelitian mantra panawar dalam bidang kesehatan. Inventarisasi dan kajian mantra Banjar yang belum terjamah dapat pula dilakukan, seperti mantra pakasih, pambanci, pikaras, dan pirunduk.

\section{DAFTAR PUSTAKA}

Arifin, E. Zaenal, dkk. 2015. Wacana Transaksional dan Interaksional dalam Bahasa Indonesia. Tangerang: Pustaka Mandiri.

Chaer, Abdul. 2012. Linguistik Umum. Jakarta: Rineka Cipta.

Humaedi, M. Alie. 2016. Etnografi Pengobatan Praktik Budaya Peramuan dan Sugesti Komunitas Adat Tau Taa Vana. Yogyakarta: Lkis.

Holmes, Janet. 1992. An Introduction to Sociolinguistics. New York: Longman Group VK Limited.

Ismail, Abdurrahman, dkk. 1996. Fungsi Mantra dalam Masyarakat Banjar. Jakarta: Pusat Pembinaan dan Pengembangan Bahasa, Departemen Pendidikan dan Kebudayaan.

Keraf, Gorys. 2006. Diksi dan Gaya Bahasa. Jakarta: Gramedia Pustaka Utama.

Kridalaksana, Harimurti. 2011. Kamus Linguistik. Jakarta: Gramedia Pustaka Utama.

Laelasari dan Nurlailah. 2008. Kamus Istilah Sastra. Bandung: Nuansa Aulia.

Mahsun, M.S. 2013. Metode Penelitian Bahasa: Tahapan Strategi, Metode, dan Tekniknya. Jakarta: RajaGrafindo Persada.

Moleong, Lexy J. 2002. Metode Penelitian Kualitatif. Bandung: Remaja Bandung.

Mulyana, Deddy. 2001. Metodologi Penelitian Kualitatif Paradigma Baru Ilmu Komunikasi dan Ilmu Sosial Lainnya. Bandung: Remaja Rosdakarya.

Nurgiyantoro, Burhan. 2012. Teori Pengkajian Fiksi. Yogyakarta: Gadjah Mada University Press.

Putrayasa, Ida Bagus. 2010. Kalimat Efektif (Diksi, Struktur, dan Logika). Bandung: Refika Aditama.

Saputra, Heru S. P. 2007.Memuja Mantra. Yogyakarta: LkiS.

Subroto, Edi. 1992. Pengantar Metoda Penelitian Linguistik Struktural. Surakarta: Sebelas Maret University Press.

Sudaryanto. 1993. Metode dan Aneka Teknik Analisis Bahasa. Yogyakarta: Wacana University Press.

- - - - - - . 2015. Metode dan Aneka Teknik Analisis Bahasa Pengantar Penelitian Wahana Kebudayaan secara Linguistis. Yogyakarta: Sanata Dharma University Press.

Sudikan, Setya Yuwana. 2001. Metode Penelitian Sastra Lisan. Surabaya: Citra Wacana.

Sulistyowati, Endang dan Tajuddin Noor Ganie. 2012. Sastra Banjar Genre Lama Bercorak Puisi. Kalimantan Selatan: Tuas Media.

Susilawati, Erni. 2016. “Nilai-Nilai Motivasi Pendidikan dalam Novel Galuh Hati; Tiga Cinta Satu Rahasia Karya Randu Alam". Dalam Genta Bahtera Jurnal Ilmiah Kebahasaan dan Kesastraan. Vol. 2, No. 1, hlm. $42-51$.

Sutana, Dwi. 2015. "Pemakaian Bahasa Indonesia pada Kolom Surat Pembaca dalam Surat Kabar Harian Haluan Kepri". Dalam Genta Bahtera Jurnal Ilmiah Kebahasaan dan Kesastraan. Vol.1, No. 1, hlm. $1-9$.

Usman, Fajri. 2009. “Bentuk Lingual Tawa Pengobatan Tradisional Minangkabau (Analisis Linguistik Kebudayaan)". Dalam Jurnal Ilmiah Bahasa dan Sastra. Vol 5 Nomor 1.

Yayuk, Rissari, dkk. 2006. Mantra Banjar. Banjarbaru: Balai Bahasa Banjarmasin. 